\title{
Namelessness from Artaud to Beckett
}

\author{
Sam Slote \\ School of English, Trinity College Dublin, Ireland \\ slotes@tcd.ie
}

\begin{abstract}
After a period of electroshock therapy, Antonin Artaud claimed to have been able to regain his name and sense of self. The dehiscence of name and identification is reprised in Artaud's final work, the radio play Pour en finir avec le jugement de Dieu. This consists of five texts, read by four people. Each text is followed by unintelligible, glossolalic screams performed by Artaud, as if Artaud were reacting against the speech acts performed by others in his name. The structure of this play suggests the predicament of Beckett's Unnamable: an entity reacting in pain to its attempts to articulate itself in a language that is not his, but theirs.
\end{abstract}

\section{Résumé}

Après avoir subi une série d'électrochocs, Antonin Artaud déclara qu' il avait retrouvé son nom et son identité. La déhiscence du nom et de l' identité constitue un des sujets fondamentaux d' une des dernières œuvres d'Artaud: la pièce radiophonique Pour en finir avec le jugement de Dieu. Divisée en cinq textes, lus par quatre personnes et suivis de cris glossolaliques inintelligibles exécutés par Artaud, la pièce met en scène la réponse d'Artaud aux actes de parole effectués par autrui en son nom. La structure de cette pièce évoque l'Innommable de Beckett: un être qui tâche péniblement de s'articuler dans un langage qui n' est pas le sien.

\section{Keywords}

Beckett - Artaud - Deleuze - irony - nominalism - Derrida 
During his six-week visit to Ireland in 1937, an increasingly agitated Antonin Artaud suffered a breakdown in which, among other symptoms, he felt that his name, the signifier 'Antonin Artaud,' was no longer his, of him. His increasingly erratic and occasionally violent behaviour led to his expulsion from Ireland as an "undesirable." His difficulties in Ireland were exacerbated by his inability to speak English (Shafer 2016, 151-153). Artaud was, effectively, both unnamable and trapped in a foreign language. Upon his repatriation, he was remanded to a psychiatric hospital. He spent the next nine years in various sanatoria, primarily at the asylum of Rodez, where he endured bouts of electroshock under the supervision of Dr Gaston Ferdière. The electroshock treatments were interspersed with some art therapy (which included some translation-work); all as a means of regaining a self or a sense of self. After his treatment he wrote Ferdière, 'j' ai subi ces derniers temps une secousse terrible mais salutaire; et maintenant qu' elle est passée je me sens retrouver la maitrise de moi. [...] Je m' appelle Antonin Artaud parce que je suis fils d'Antoine Artaud et d'Euphrasie Artaud" (recently I have endured a terrible but salutary shock; and now that it's over I feel that I have regained self-control. [...] My name is Antonin Artaud because I am the son of Antoine Artaud and Euphrasie Artaud; qtd. in de Mèredieu 1996, 125; my translation). It is as if he were cured, mirabile dictu. But it is important to see the ambiguity in Artaud's self-diagnosis: "Je m' appelle Antonin Artaud," which literally (although not colloquially) means I call myself Antonin Artaud because that is what I have been called by my parents ("parce que je suis fils d'Antoine Artaud et d'Euphrasie Artaud"), by others. He has not necessarily regained his name so much as he has grokked the subterfuge of the speech act, or more precisely, the subterfuge of the nominative and auto-nominative speech act. In this, Artaud's madness and recovery indicate the brute, sinister implications of nominalist irony. Indeed, "Ci-Gît," one of the texts he wrote in 1947, after his release, starts with a line that asserts a possibility of a cure whilst also partially undermining his claim to Ferdière: "Moi, Antonin Artaud, je suis mon fils, mon père, ma mère, / et moi" ("I, Antonin Artaud, am my son, my father, my mother, and myself"; Artaud 1974, vol. 12, 77; Artaud 1976, 540). He has a name, but he is, allin-all, self-sufficient and self-creating unto himself. He calls himself Antonin Artaud because he tautologically contains multitudes. It is as if calling himself Antonin Artaud were itself a work of some art: Artaud le mômo and Artaud the monad.

After his therapy and confinement, Artaud did regain his artistic faculties and was able, in his final months, to create some truly unusual and disturbing pieces, such as Le Retour d'Artaud le mômo, and the radio play Pour en finir avec le jugement de Dieu. Derrida characterises these final works, written 
after the brutality of therapy, as marked by "an unnamable passion to which no other resource remained than to rename and reinvent language" (Derrida 2002, 20; Kamuf 2017, 84). Indeed, the radio play Pour en finir avec le jugement de Dieu certainly seems haunted by an unnamable passion. The play consists of five texts which were read by four people: Artaud, Maria Casarès, Paule Thévenin and Roger Blin, Artaud's friend and colleague since 1928 (Shafer 2016, 121) and who would, of course, go on to direct the first production of Beckett's Godot. ${ }^{1}$ One of the texts for Pour en finir, called "Tutuguri," was originally drafted in 1936 and another, "La Question se pose de ...," was written shortly before Artaud was approached by Fernand Pouey, the director of RDF (Radio diffusion française), with a commission for a radio play for the series "La Voix des poètes." The rest of the texts were written specifically for the commission. A sixth text, while written, was never recorded. Unsurprisingly the broadcast, planned for 2 February 1948, was cancelled; besides the general strangeness and unpleasantness of the play, it also contained some anti-American content that was not in keeping with the post-War spirit in France. Artaud's expressionself or otherwise-was censored for the radio, but the script was published in $1948 .^{2}$

Each of the texts is written in the first-person singular and with the implication that they are mostly of and from a persona ostensibly named Antonin Artaud. For example, in the part called "La Recherche de la fécalité," which was read by Blin, a particularly blasphemous section is followed by the sentence within quotation marks, thus suggesting an interjection by someone else, "Vous êtes fou, monsieur Artaud" ("You are mad Mr. Artaud"; Artaud 1974, vol. 13, 86; Artaud 1976,562$)$. In the radio play these are all spoken by a variety of voices, male and female. Artaud himself only read the conclusion. His main contribution to the play is a series of glossolalic sounds, screams, and unspecified percussive and xylophonic sounds that serve as the segues between each of the play's parts. It is no longer cogito ergo sum, but rather, others speak, therefore I scream. These interstitial screams are not indicated at all in the published text, instead they only exist in the recording.

During the radio play, it is as if others take the name of Artaud; others say or imply the speech act "Je m' appelle Antonin Artaud." The conclusion provides a stark example of this as it takes the form of an interview, with Artaud playing the roles of both parties: "Vous énoncez là, monsieur Artaud, des choses bien

1 When Beckett wrote to Georges Duthuit on 27 February 1950 to tell him that Blin was interested in putting on Godot, he described him as a "grand ami d' Artaud" (Beckett 2011, 179).

2 The history of the programme and the controversy over its broadcast is recounted in Artaud (1974, vol. 13, 323-324). 
bizarres.' 'Oui, je dis une chose bizarre'” “"You are saying some very bizarre things, Mr. Artaud.' 'Yes, I am saying something bizarre' "; Artaud 1974, vol.13, 101; Artaud 1976, 568). The 'questioner' tells "Artaud" he is saying bizarre things, to which 'Artaud' (and this time it is Artaud) replies it is just the one bizarre thing he is saying, which suggests the possibility that the strangeness is not confined to the content of the speech act (that is, any of the various things he is saying), but rather, perhaps, to the very act of speaking itself: the fact that Je dis is indeed une chose bizarre. This mock-interview thus performs the fundamental disjunction of self-identity, as famously and pithily put by Arthur Rimbaud, in a letter to Paul Demeny, "JE est un autre" (I is an other; Rimbaud 1990, 43; my translation). The "I" is naught but quotation.

So, in Pour en finir avec le jugement de Dieu, amidst these various speech acts performed by others in his name, Artaud himself screams and reacts in pain, in pain as speech acts in his name are performed by others. He is taunted by others in his name, taunted by others inhabiting his name. This structure of an entity reacting to its being spoken by others recalls Beckett's That Time in which a face silently responds and reacts to the same addressing voice, broadcast from three locations in a manner that is "clearly faintly perceptible" (Beckett 2009, 97), as the stage directions (helpfully) put it. And, as Ulrika Maude (even more helpfully) puts it, in that play, "the voice, and by extension the subject, is divided against itself through diverse spatial and temporal positioning" (67). But, in contrast, in Pour en finir, voice and identity are disjunct without reference to spatio-temporal positioning and, in this way, Artaud's radio play more directly recalls the situation of Beckett's own Unnamable: an entity divided by language in language, specifically in a language that is inevitably alien, that is, of others. As he says, at the start, "I seem to speak, it is not I, about me, it is not about me" (Beckett 2010a, 1). The Unnamable is enmeshed within and non-dissociable from the language of others: "I have to speak, whatever that means. Having nothing to say, no words but the words of others, I have to speak" (25). The Unnamable is trapped in a language ever-foreign because he is forever atopian. Not just uncertain about the characteristics of his place, he is uncertain as to its very placeness, "that would be a blessed place to be, where you are" (91).

Beckett's Unnamable and Artaud's Pour en finir are thus reciprocal and mutually illuminating texts. If the Unnamable only has the words of others, in Pour en finir others have Artaud's words. Like the Unnamable-ever haunted and taunted by his "manikins" (17), the "two fomenters of fiasco" (51), "their miscreated puppets" (37), and his "delegates" (7) —Artaud is displaced in the voices of proxies. The act of self-identification is inherently fissile in that it involves an identification of self as proxy. 
In the mock-interview at the proximate conclusion of Pour en finir-that is, the conclusion as recorded but not as written - the speaking subject is split into a questioner and a respondent where both are performed by the one actor and thus neither is properly distinguishable: the one and the other are the same. This has an analogy when the Unnamable at one point realises of itself and its proxy Mahood, "What if we were one and the same after all, as he affirms, and I deny?" (26). If they were one and the same, then they would either both deny or both affirm and so this question is perfectly exemplary of what Thomas Trezise calls the Unnamable's "fundamentally non-self-coincidental voice" (138), that is, it is itself a contradictory statement or a statement that is non-self-coincidental. It performs its non-self-coincidence; or perhaps more accurately, non-self-coincidence is performative. Likewise, Pour en finir enacts a non-self-coincidence of Artaud and of speaking in Artaud's name. Thus both The Unnamable and Pour en finir are (each) non-self-coincidental texts. Such a predicament is further exacerbated for each text when we additionally consider the non-self-coincidence between L'Innommable and The Unnamable ${ }^{3}$ and, on the other hand, the non-self-coincidence between the printed text of Pour en finir and the recording made for RDF.

Indeed, non-self-coincidence is entirely the problem when it comes to speaking of the voice (as it were). As Van Hulle and Weller note, it is perhaps significant that Beckett wrote his first two radio plays while he was struggling with translating L'Innommable (Van Hulle and Weller 2014, 185). While thinking though the re-articulation of voice into another language (English), Beckett also engages with the re-articulation of voice into another medium (radio). Or, perhaps, the re-de-articulation of the voice would be a more accurate rubric with which to understand the translation of L'Innommable into The Unnamable. Joe Milutis describes Artaud's radio plays in such terms: "the radiophonic universe takes the voice away from the body, stealing words-as in Artaud's paranoid scenario - and transmitting them everywhere" (Milutis 1996, 65). In Artaud's radio plays - as in Beckett's Unnamable - the voice is untethered, taken away from the body, but only so far.

The text within Pour en finir that I want to look at in order to tease out further contiguities with The Unnamable is the penultimate one, "La Question se pose de ...," which is immediately followed by the play's longest and most sustained burst of Artaud's screams. This was read by Paule Thévenin for the RDF

3 To take a famous example, and there are many, the French begins with the questions "Où maintenant? Quand maintenant? Qui maintenant?" (Beckett 1953, 7), the order of which is different in the English, "Where now? Who now? When now" (1); see also Van Hulle and Weller (2014, 190-195). 
recording. This piece begins with the possibility that there is another, which while unknown and unknowable is, somehow, there, somewhere.

\author{
Ce qui est grave \\ est que nous savons \\ qu' après l' ordre \\ de ce monde \\ il y en a un autre.
}

Quel est-il?

Nous ne le savons pas.

ARTAUD 1974, vol. 13, 91

What makes it serious

is that we know

that after the order

of this world

there is another.

What is it like?

We do not know.

ARTAUD $1976,5^{62-563}$

As with The Unnamable, the persona here resides within a linguistic, epistemological, and even ontological negativity. Unlike the convolutions of The Unnamable, at least for the moment, this negativity is described in ways that are not yet immediately infected by that negativity. That is, the uncertainty is, more or less, expressed clearly. The realms of the unknowable continue down from alterity to infinity to consciousness:

Et qu' est-ce au juste que la conscience?

Au juste nous ne le savons pas.

C' est le néant.

Un néant

dont nous nous servons 
pour indiquer

quand nous ne savons pas quelque chose

ARTAUD 1974, vol. 13, 92

And precisely what is consciousness?

That is precisely what we do not know.

It is nothingness.

A nothingness

that we use

to indicate

when we do not know something

ARTAUD 1976, 563

Consciousness is both unknown and it is a nothingness and this nothingness is itself a mask hoisted over an unknown. The nothing is, in a sense, pronominal: a thing in place of no thing, or, more precisely, a nothing in place of a deeper unknown. According to the voice, this supplementation is felt physically: it is an embodied experience of wanting to leave the body, an embodied ex-bodiment.

Indeed, as this speech continues, consciousness becomes equated with appetite, "au désir sexuel / et à la faim" ("to sexual desire / and to hunger"; Artaud 1974, vol. 13, 92; Artaud 1976, 564), but then also, more fundamentally, "la conscience / est un appétit, / l' appétit de vivre" ("consciousness / is an appetite / the appetite for living"; 93; 564). This is what the voice-in Artaud's nameis, in effect, saying: go on, you want to live, you are hungry for life, hungry for life in a body that imposes its own imperatives:

l' espace de la possibilité

me fut un jour donné

comme un grand pet

que je ferai;

ARTAUD 1974, vol. 13, 93

The space of possibility

was given to me one day

like a loud fart

that I will make

ARTAUD 1976, 565 
The body in question itself also speaks an inarticulate cry, the fart. While the Unnamable is an asexual creature, ${ }^{4}$ it is also subject to indeterminate bodily expulsions: "After so long a silence, a little cry, stifled outright. What kind of creature uttered [...] Is Malone the culprit? Am I? Is it not perhaps a simple little fart, they can be rending" (Beckett 2010a, 6). For both the Unnamable and the persona of Artaud's play, the extirpation of bodily gas only ambiguously vouchsafes the identity of the organism. Or, as my eight-year-old son might put it, no one knows who really farted. And around this ambiguity exists language which always fails at diagnosing the matter:

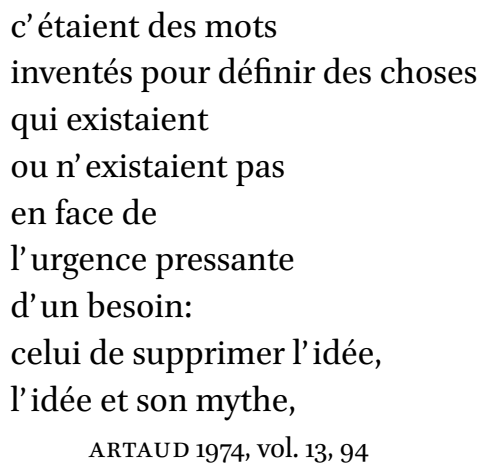

they were words invented to define things that existed or did not exist in the face of the pressing urgency of a need: the need to abolish the idea the idea and its myth, ARTAUD 1976, 565

Malone, in all his mortal liveliness, is a bit more sanguine in the matter of linguistic unreliability, "There is no use indicting words, they are no shoddier than what they peddle" (20). Linguistic negativity only indicates, and fallibly, a deeper ontological negativity. Language perpetuates only inability and ignorance.

4 At one point the Unnamable asks the question Tristram Shandy should well have asked, "Why should I have a sex, who have no longer a nose?" (Beckett 2010a, 15). 
Je ne sais pas

mais

je sais que

l' espace,

le temps,

la dimension,

le devenir,

le futur,

l' avenir,

l'être,

le non-être,

le moi,

le pas moi,

ne sont rien pour moi;

ARTAUD 1974, vol. 13, 95

I do not know

but

I do know that

space,

time,

dimension,

becoming,

future,

destiny,

being,

non-being,

self,

non-self,

are nothing to me;

ARTAUD 1976, 566

What he does know is the force of something wanting to get out: "mais il y a une chose / qui est quelque chose, / [...] / et que je sens / à ce que ça veut / sorTiR: / la présence / de ma douleur / de corps" ("but there is a thing / which is something, / [...] / and which I feel / because it wants / TO GET OUT: / the presence / of my bodily / suffering"; Artaud 1974, vol. 13, 95-96; Artaud 1976, $566)$. Something wants to get out, this something only has identity insofar as it is vectoral: that it wants to leave. Precisely because an exteriority is implied, there then comes the possibility of an ambiguous and pernicious alterity: "et ce 
point / c' est quand on me presse" ("and this point / comes when they press me"; Artaud 1974, vol. 13, 96; Artaud 1976, 567). And what this external, ambiguous alterity "on" (they) imposes is desire:

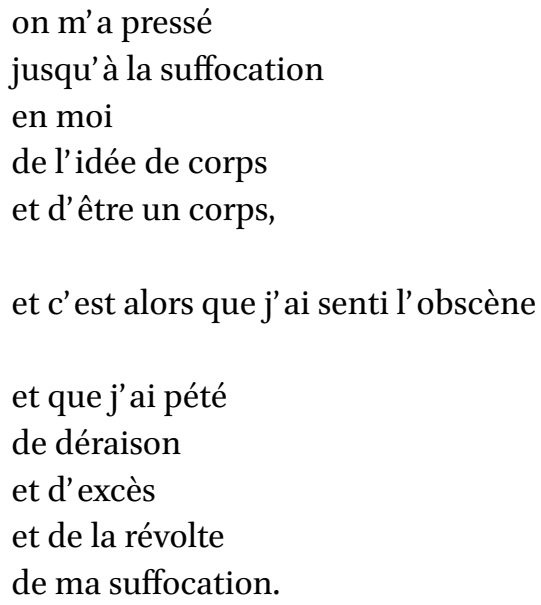

they pressed me until the idea of body and the idea of being a body was suffocated in me,

and it was then that I felt obscene

and that I farted

from folly

and from excess

and from revolt

at my suffocation.

ARTAUD 1976, $567-568$

This section then ends with bold-faced text: "et c' est alors / que j' ai tout fait éclater / parce qu' à mon corps / on ne touche jamais" ("and it was then / that I exploded everything / because my body / can never be touched"; Artaud 1974, vol. 13, 97; Artaud 1976, 568). And then come Artaud's (own) loud and violent screams and bangs. The persona has, during this section, delivered a not-illogical argument concerning the possibility of something-some knowl- 
edge, some iota, some fragment, some gas - that is proper to the self, proper to the self that is otherwise being suffocated by others. Within language it defines such a something in a sort of 'eureka' moment, the explosion from the body that cannot be touched, the body not cathected to anything. But, of course, such ratiocination about expulsion, such as it is, is performed by someone else in Artaud's name. The attempt at authenticity is itself alienated from Artaud. This, then, would be why Artaud screams. He reacts against the flatulent solution performed in his name by a proxy.

In the final section, in the mock-interview, Artaud proposes, again, his solution of a kind of Nietzschean transvaluation of the body, the self, and of value itself. In the radio play this was performed by Artaud himself; after the screams, his voice finally takes over:

L'homme est malade parce qu' il est mal construit.

Il faut se décider à le mettre à nu pour lui gratter cet animalcule qui le démange mortellement,

$$
\begin{aligned}
& \text { dieu, } \\
& \text { et avec dieu } \\
& \text { ses organes. }
\end{aligned}
$$

Car liez-moi si vous le voulez,

mais il n'y a rien de plus inutile qu'un organe.

Lorsque vous lui aurez fait un corps sans organes,

alors vous l' aurez délivré de tous ses automatismes et rendu à sa vérita-

ble liberté.

ARTAUD 1974, vol. 13, 104

Man is sick because he is badly constructed.

We must make up our minds to strip him bare in order to scrape off that animalcule that itches him mortally,

$$
\begin{aligned}
& \text { god, } \\
& \text { and with god } \\
& \text { his organs. }
\end{aligned}
$$

For you can tie me up if you wish, but there is nothing more useless than an organ. 
When you will have made him a body without organs,

Then you will have delivered him from all his automatic reactions and restored him to his true freedom.

ARTAUD 1976, 570-571

To be done with the judgement of God, to disconnect from God, is to disconnect from desire, to remake man and become the body without organs, the body without cathexis. Gilles Deleuze and Félix Guattari take this prompt of Artaud's "corps sans organes" as their alternative to the desiring machines hoisted by capitalism. According to Deleuze and Guattari's reading of Artaud, the judgement of God is effected through the conceptualization of the body as a hierarchical entity which can be controlled and coordinated and, indeed, judged. ${ }^{5}$ In short, organs are how the body is subjected, subjectified, and made useful to the powers-that-be.

The judgment of God, the system of the judgment of God, the theological system, is precisely the operation of He who makes an organism, an organization of organs called the organism, because He cannot bear the $\mathrm{BwO}$, because He pursues it and rips it apart so He can be first, and have the organism be first.

DELEUZE and GUATTARI 1980, 196-197; MASSUMI 1987, 158-159

In distinction, the body without organs is what resists such control and such being-towards-utility. Obviously, in coining the phrase "corps sans organes," and in railing against normativizing forces of control, Artaud stands for Deleuze and Guattari as a key example and proponent of the otiose "nonorganic" resistance, as exemplified in his screams, which can purportedly jumble the codes of control and organization. Likewise, for them, Beckett's texts also suggest zones of resistance to and possible freedoms from the judgement of, let us say, God. Resistance comes in slipping through the cracks: "a pure dispersed and anarchic multiplicity, without unity or totality, and whose elements are welded, pasted together by the real distinction or the very absence of a link. Such is the case in the schizoid sequences of Beckett" (Deleuze and Guattari 1972, 387; Hurley, Seem, and Lane 1983, 324). However, disentangling Artaud from Deleuze and Guattari, we can see that Artaud's point might not perfectly align with their soi-disant schizoanalysis. Indeed, there is a passage

5 In this, Deleuze and Guattari follow from Derrida's essay on Artaud "La Parole soufflée" (originally published in 1965): "God is thus the proper name of that which deprives us of our own nature, of our own birth" (Derrida 1967, 269; Bass 1978, 181). 
in The Unnamable that seems to directly follow from the end of Artaud's radio play, but not necessarily in such a way as to accord with Deleuze and Guattari's groovy conscription of Beckett to the resistance against the first order of God:

Organs, a without, it's easy to imagine, a god, it's unavoidable, you imagine them, it's easy, the worst is dulled, you doze away, an instant. Yes, God, fomenter of calm, I never believed, not a second. No more pauses either. Can I keep nothing then, nothing of what has borne my poor thoughts, bent beneath my words, while I hid? I'll dry these streaming sockets too, bung them up, there, it's done, no more tears, I'm a big talking ball, talking about things that do not exist, or that exist perhaps, impossible to know, beside the point. Ah yes, quick let me change my tune. And after all why a ball, rather than something else, and why big?

BECKETT 2O1Oa, 16

Part of the tantalizing, seeming closeness to Artaud comes from this being in English, "Organs, a without, it's easy to imagine"; in French, on the other hand, it's not quite as lexically proximate, "Des organes, un dehors, c' est facile à imaginer" (Beckett 1953, 31). According to the Unnamable, it is easy to imagine organs and exteriority and the concomitant connection to exteriority implied by organs. It seems as if the Unnamable is proposing a similar thesis to the pseudo-Artaud of the conclusion of Pour en finir: organs are what connect to alterity in general and the grand alterity of God. This is, I think, the key, subtle difference that unwinds Beckett and maybe even Artaud from Deleuze and Guattari. God is, not just he who judges, but the "fomenter of calm"; in the French this is the slightly more pejorative "fauteur de calme" (31), which also, through the overtone of the word faute, suggests the mendacious nature of such calm. God is the proxy par excellence. Indeed, the phrase "fomenter of calm" recalls one of the Unnamable's derogatory names for his proxies, "fomenters of fiasco" (51); in French, likewise, "fauteurs de fiasco" (86). God is the pseudo-palliative for the body without organs, an uneasy and nasty, but nonetheless seductive palliative. But this divine palliative, in its fake calm, only exacerbates rather than soothes the pain suffered by the big talking ball. The Leibnizian monad, the body without organs is (still) not without pain.

While he does not mention Artaud, Jean-Michel Rabaté notes that this passage anticipates yet also refutes Deleuze and Guattari's conceptualization of Artaud's body without organs: "God and man are locked in an articulation that frustrates the Deleuzian impulse to push the speaking and desiring subject beyond the human altogether" (41). In effect, Deleuze and Guattari have made 
Beckett and Artaud tools in their critique and opposition to capitalist utilitarian organization. Whereas Beckettian resistance is such that it resists being made into a tool of resistance.

Artaud's radio play is about being done with one thing in order to start another: finishing with the judgement of God-pour en finir avec le jugement de dieu - in order that the human being can be rebuilt as a body without organs, and, if Deleuze and Guattari are to be believed, a body without the pains of alterity, a body without cathexis to the without. But this body without organs might not be liberatory, which is the implication of the Unnamable's discourse. To be finished with the judgement of God is still, unfortunately, to go on. Instead of a libidinal transvaluation, the Unnamable is stuck within his progressive aporia hoping for the end that never comes and which, in never coming, forces continuation. One can never be finished with the judgement of God because one can never be finished with oneself, and with all the attendant problems and paradoxes that that implies. Artaud hopes to be finished with God, Beckett just hopes to be finished; as we have with the faint, optative cry that closes Stirrings Still, "Oh all to end" (Beckett 2009, 115); in French, "Oh tout finir" (Beckett 1989, 28). Ending in Beckett is intransitive, whereas for Artaud it is transitive, all too transitive.

Pour en finir is, of course, not the same text as The Unnamable, but both texts are, in their own ways, performances of self-dis-identity, that is, the selfalienation presented in each text is performative. In Pour en finir the selfdis-identity is performed through the structure of others speaking in Artaud's name and in The Unnamable it comes through the text's progression through cycles and epicycles of contradictions. If the Unnamable hopes to arrive at the statement that will end him, by the end he wonders if perhaps he has already said this definitive statement without having known about it: "Perhaps I've said the thing that had to be said, that gives me the right to be done with speech, done with listening, done with hearing, without my knowing it" (Beckett 2010a, 112). Likewise, in Stirrings Still, it is hypothesized that this end might have already been said and merely (merely!) needs to be excavated and unconcealed: "In any case whatever it might be to end and so on was he not already as he stood there all bowed down and to his ears faint from deep within again and again oh how something and so on was he not so far as he could see already there where never till then?" (Beckett 2009, 114). So, likewise, even if the Unnamable has said the last word, the word that gives him the right to be done with speaking, he is still speaking, still going on.

The Unnamable is a linguistic entity trapped within language trying to speak its way out. In other words (and always in other words), it tries to use language to out-language language. Such a negative tautology is not exactly possible; 
hence the problem he faces, repeated numerous times, in various modalities across the text, "by affirmations and negations invalidated as uttered, or sooner or later" (Beckett 2010a, 1). Its proxies are but an effect of this proliferating discourse contra discourse. The Unnamable (the novel) and the Unnamable (the entity) are entirely of and within language (or languages, if one wants to refer to both the English and French texts). The Unnamable is, then, an extreme version of what Paul de Man defined as literature: "the place where this negative knowledge about the reliability of the linguistic utterance is made available" (10). Indeed, The Unnamable twists this inward one step further into a representation of the lived experience of this negative knowledge as itself being a painful spur to perpetuate discourse: "The search for the means to put an end to things, an end to speech, is what enables discourse to continue" (10). In this way, the full text of The Unnamable is analogous to Artaud's screams in that both descry the pain of continuing expression, expression that continues under one name or another. Indeed, at one point the Unnamable suggests the possibility that he has been screaming all along:

they stop to listen to my screams, they'll never stop again, yes, they'll stop, my screams will stop, from time to time, I'll stop screaming, to listen and hear if anyone is answering, to look and see if anyone is coming, then go, close my eyes and go, screaming, to scream elsewhere. Yes, my mouth, but there it is, I won't open it, I have no mouth, and what about it, I'll grow one, a little hole at first, then wider and wider, deeper and deeper, the air will gush into me, and out a second later, howling. But is it not rather too much to ask, to ask so much, of so little, is it really politic? And would it not suffice, without any change in the structure of the thing as it now stands, as it always stood, without a mouth being opened at the place which even pain could never line, would it not suffice to, to what, the thread is lost, no matter, here's another.

101

The contemplation of the possibility of a mouth is itself a further prosthesis for discourse to limp on just a bit more until the next thread carries over. Scream or language, it's all the same in that it all goes on, finitude without end. The words of the Unnamable and the cries of Artaud — the cries of his "unnamable passion" (Derrida 2002, 20; Kamuf 2017, 84) —are thus like the old woman at the start of Ill Seen Ill Said who "rails at the source of all life" (Beckett 2009, 45).

In the "Post-Scriptum" to Pour en finir, which was never recorded (and is not included in the translation in Selected Writings) — and there is no record of whose voice this would have been in were it recorded-Artaud states his 
name and identity proudly and clearly: “Qui suis-je? / D' où je viens? / Je suis Antonin Artaud / et que je le dise / comme je sais le dire / immédiatement / vous verrez mon corps actuel / voler en éclats / et se ramasser / [...] un corps neuf / où vous ne pourrez / plus jamais / m'oublier" (Who am I? / Where do I come from? / I am Antonin Artaud / and as I say / as I can say / immediately / you will see my current body /shatter / and retrieve itself / [...] a new body / where you will never / never again / forget me; Artaud 1974, vol. 13, 118; my translation). Unlike the letter to Ferdière, here he is clear about his embodied identity as Antonin Artaud: he is Antonin Artaud, hear him roar and never forget. Of course, this piece was never recorded, the statement never quite made, and it remains only as textual detritus. The statement of identity is draff, draff by proxy in both Artaud's Pour en finir and the Unnamable's progressive aporia, "Oh tout finir."

\section{Works Cited}

Artaud, Antonin, CEuvres complètes, vol. 12 (Paris: Gallimard, 1974).

Artaud, Antonin, QEuvres complètes, vol. 13 (Paris: Gallimard, 1974).

Artaud, Antonin, Selected Writings, ed. Susan Sontag, tr. Helen Weaver (New York: Farrar, Straus and Giroux, 1976).

Beckett, Samuel, L'Innommable, 1987 ed. (Paris: Minuit, 1953).

Beckett, Samuel, Soubresauts, 1989 ed. (Paris: Minuit, 1989).

Beckett, Samuel, Krapp's Last Tape and Other Shorter Plays, ed. S.E. Gontarski (London: Faber, 2009).

Beckett, Samuel, Company, Ill Seen Ill Said, Worstward Ho, Stirrings Still, ed. Dirk Van Hulle (London: Faber, 2009).

Beckett, Samuel, The Unnamable, ed. Steven Connor (London: Faber, 2010a).

Beckett, Samuel, Malone Dies, ed. Peter Boxall (London: Faber, 2010b).

Beckett, Samuel, The Letters of Samuel Beckett, vol. II: 1941-1956, ed. George Craig, Martha Dow Fehsenfeld, Dan Gunn, Lois More Overbeck (Cambridge: Cambridge UP, 2011).

Deleuze, Gilles and Félix Guattari, L'Anti-OEdipe (Paris: Minuit, 1972).

Deleuze, Gilles and Félix Guattari, Mille plateaux (Paris: Minuit, 1980).

Deleuze, Gilles and Félix Guattari, Anti-CEdipus, tr. Robert Hurley, Mark Seem, Helen R. Lane (Minneapolis: $\mathrm{U}$ of Minnesota P, 1983).

Deleuze, Gilles and Félix Guattari, A Thousand Plateaus, tr. Brian Massumi (Minneapolis: $\mathrm{U}$ of Minnesota $\mathrm{P}, 1987$ ).

De Man, Paul, The Resistance to Theory (Minneapolis: Up Minnesota, 1986).

Derrida, Jacques, L'Écriture et la différence (Paris: Seuil, 1967). 
Derrida, Jacques, Writing and Difference, tr. Alan Bass (Chicago: U of Chicago P, 1978). Derrida, Jacques, Artaud le Moma (Paris: Galilée, 2002).

Derrida, Jacques, Artaud the Moma, tr. Peggy Kamuf (New York: Columbia UP, 2017). Maude, Ulrika, Beckett, Technology and the Body (Cambridge: Cambridge UP, 20o9). De Mèredieu, Florence, Sur l'électrochoc: le cas Antonin Artaud (Paris: Blusson, 1996). Milutis, Joe, "Radiophonic Ontologies and the Avantgarde," in TDR 40.3 (1996), 63-79. Rabaté, Jean-Michel, Think, Pig! (New York: Fordham UP, 2016). Rimbaud, Arthur, Lettres de la vie littéraire (Paris: Gallimard, 1990).

Shafer, David A., Antonin Artaud (London: Reaktion, 2016).

Trezise, Thomas, Into the Breach (Princeton: Princeton UP, 199o).

Van Hulle, Dirk and Shane Weller, The Making of Samuel Beckett's L' Innommable/The Unnamable (Brussels: up Antwerp / London: Bloomsbury, 2014). 